\title{
Bleaching of Caribbean corals a cause for concern
}

Washington

AN unusual event is occurring in the Caribbean. Reef corals from Colombia to Bermuda are losing their symbiotic algae, exposing the pale underlying coral skeletons, and possibly leading to widespread coral death. Although similar events have been recorded in the past, marine biologists from the region visited a snowy Capitol Hill last week to persuade Congress of the importance of tracking this episode and trying to determine its cause.

Reef coral play an important role in the marine ecosystem. Not only do they protect shorelines by forming a natural breakwater, but they are also an important nutrient source for other marine life, producing between 300 and 5,000 grams of carbon per square metre per year. The first indications that corals were losing their algae - a process known as bleaching - came from observations in mid-July at the Islas del Rosario off the coast of Colombia. When stressed, corals will lose the nitrogen-fixing zooxanthellae that normally attach to their skeletons. Stress can come from high water temperatures, increased suspended sediment or nutrients, and hypersalinity. Pathogens may also be causes for the bleaching, or possibly some interactive phenomenon that renders the zooxanthellae more sensitive to ultraviolet radiation.

In written testimony presented to the Senate appropriations subcommittee

\section{New AFRC secretary}

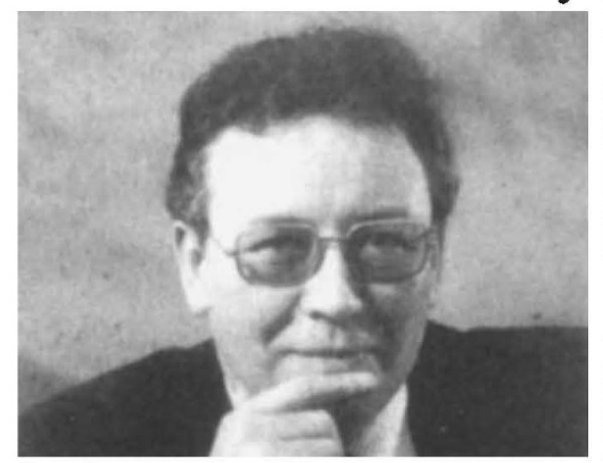

London

THE Agricultural and Food Research Council (AFRC) has appointed Professor William D.P. Stewart as secretary to the council from 1 January 1988 . He succeeds the late Professor John Jinks who died in post in June 1987. Stewart is a plant and microbial physiologist interested in nitrogen fixation and cycling and has many links with AFRC; he is a past member of the AFRC Plants and Soils Research Grants Board and is Royal Society Assessor to the Council.

Sarah Hargreaves looking into the Caribbean event, Judith Lang, curator of invertebrate zoology at the Texas Memorial Museum of the University of Texas at Austin, claimed that the widespread distribution of the event "suggests that some large-scale physical factor(s) is involved". John Ogden, director of West Indies Laboratory of Fairleigh Dickenson University in St Croix, agrees that a physical explanation seems most likely. Ogden says the current event underscores the need for better communi-

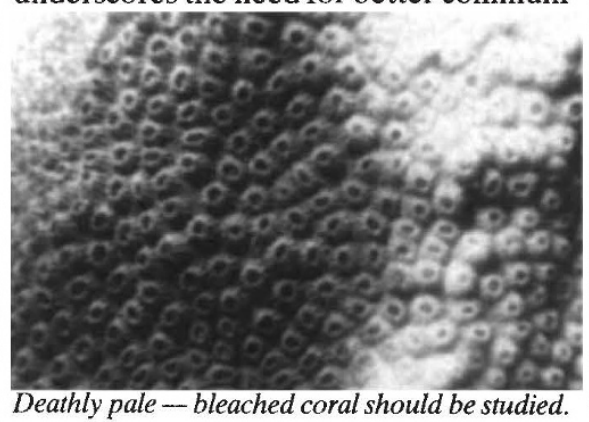

cation between marine biologists and oceanographers: the explanation may already exist in oceanic and atmospheric physical data, but oceanographers have not responded quickly.

Ernest Williams of the University of Puerto Rico says the pattern of the bleaching suggests something other than a physical factor. Although water temperatures are cooling to a temperature more favourable for coral growth, Williams says the bleaching is continuing. He believes there may be some latent disease that is being stimulated by physical conditions. Williams has the most complete records of the current event, and has sent out some 500 letters asking different sites about their experiences.

Coral bleaching has occurred in the past, as have widespread mortalities among other marine animals. Three years ago, between 95 and 99 per cent of the sea urchin Diadema antillarum were killed in the Caribbean by unknown causes, although a pathogen is suspected as the deaths were extremely species-specific. 'White band disease' has killed 90 per cent of the elkhorn coral at Buck Island Reef National Monument in St Croix.

Senator Lowell Weicker (Republican, Connecticut), an enthusiastic supporter of the National Oceanic and Atmospheric Administration Undersea Research Program (NURP), made it clear at the hearings that he expects NURP to take steps to do something about the bleaching. A meeting is planned for December among Caribbean marine laboratory directors. Ogden is optimistic that the next phase will be to watch the coral recover.

Joseph Palca

\section{CNRS gold awards}

\section{Paris}

The Centre National de la Recherche Scientifique (CNRS) has announced this year's gold medal (Prix d'Or) laureates. The award has been given to historian of science Georges Canguilhem and mathematician Jean-Pierre Serre.

Canguilhem, aged 83 , is emeritus professor at the Sorbonne. He taught at Toulouse in the 1940s, and also studied medicine, submitting a thesis on "the normal and the pathological". For 20 years he was professor of the history of science at the Sorbonne. He received the Resistance medal for wartime service, the Légion d'Honneur and the Medaille Georges Sarton.

Serre, 61, was a member of the famous Bourbaki group and his contributions to mathematics range from topology to geometry. His decorations include the distinguished Fields medal, and he is also an Officer of the Légion d'Honneur. P.C.

\section{New blood for museum} Paris

AFTER a 2-month delay, the French cabinet has nominated a new director for the Science and Industry Museum, at La Villette in Paris. He is Christian Marbach, currently president and director general of ANVAR (Agence Nationale pour la Valorisation de la Recherche), the French government agency set up to promote technological research.

'La Villette', as the museum is known, has been criticized by Research and Technology Minister Jacques Valade for costing too much since it opened in 1986 (see Nature 329, 96; 1987).

Marbach, who gained a reputation at ANVAR for sound but innovative management, is no stranger to this government's cutbacks in public spending: ANVAR's grant was halved when the government took office last year, but has crept up again with a change in policy towards technology research. Grants to La Villette were reduced by 11 per cent in last September's 1988 budget proposals.

P.C.

\section{AIDS report update}

\section{Washington}

PROMPTED both by the success and the failure of its first effort, the US Institute of Medicine (IOM) has begun work on a second edition of its report Confronting AIDS: Directions for Public Health, Health Care, and Research. When released last year, the report generated massive press coverage, and its conclusions were widely embraced, but not put into practice by federal government.

A small panel chaired by Theodore Cooper of Upjohn will assemble the report, aided by some 70 correspondents writing about different aspects of the AIDS problem. The updated edition of the report is due early next summer. 